\title{
Failure Mode Classification of RC Columns by the Analysis of the Main Bar Strain Distribution Based on the Truss and Arch Model
}

\author{
Alcantara Primo Allan*1 and Hiroshi Imai*2
}

\begin{abstract}
Synopsis : A new approach in the classification of the resulting failure mode, whether shear, bond splitting or flexure, for reinforced concrete columns is presented. Particular emphasis is placed on the analysis of the strain distribution in the main reinforcement based on the truss and arch model theory. Failure mode prediction from the proposed alternative method is compared with results from several series of column experiments. The proposed method is shown to provide a high level of precision in classifying failure modes with the proper consideration of the presence of inner rows of main bars and the effect of axial loading.
\end{abstract}

Keywords : failure mode classification, reinforced concrete column, truss and arch model, main bar strain distribution, axial load, inner rows of main bars, error estimate

\section{INTRODUCTION}

Failure of a reinforced concrete member, such as columns, are classified into three major types: shear, bond splitting and flexural modes. Although it is common practice to rely on the observed crack patterns and the yielding of the steel reinforcement to determine the resulting failure mode, problems arose for specimens exhibiting features of more than one type of failure mode. Hence, there is difficulty in the evaluation of the ultimate strength of the columns, especially whether it be for shear or for bond splitting.

An alternative approach in the classification of failure modes for reinforced concrete columns is presented. Aside from failure mode classification by the use of crack patterns, bar strains and ultimate strengths, an analysis of the strain distribution in the main reinforcement is considered. Using the proposed method gives a different perspective wherein focus is given from within the interi-

* 1 Institute of Engineering Mechanics, University of Tsukuba, Graduate Student, Member of JCI

* 2 Institute of Engineering Mechanics, University of Tsukuba, Associate Professor, Member of JCI or of the column showing the actual behavior of the main reinforcement under loading. Qualitatively, the strain distribution would show the actual bond behavior of the main bar whether or not it has exceeded the bond strength for the shear and bond splitting types. Moreover, a yielding strain distribution normally suggests a flexural type of failure.

The theoretical main bar strain distribution was derived for the different modes of failure using the theories presented in the truss and arch model. The strain distribution was determined quantitatively from equilibrium equations and material properties. Test results on reinforced concrete columns showing the strain distribution in the main reinforcement were used and compared, both qualitatively and quantitatively, with the theoretical strain distribution using the truss and arch model. Also, based on the analysis and conclusions obtained from the use of the main bar strain distribution, a discussion on the calculation of the ultimate strengths of reinforced concrete columns for the different failure modes is given.

Research reported in this paper shows that, with proper consideration of the presence of inner 
rows of main bars and axial loading, there is a good correspondence between the theoretical (truss and arch model) and experimental main bar strain distribution in reinforced concrete columns. Also, due to the underestimation of the theoretical bond splitting capacity of the columns, recommendations made in the paper would allow for a more rational consideration of the influence of the presence of inner rows of main reinforcement on the bond splitting capacity.

Therefore, the proposed classification method using the main bar strain distribution provides the following advantages in the field of scientific research of reinforced concrete columns. Firstly, though an experimental study is implicit, it is considered as a special method in the failure mode classification and an alternative to the conventional use of crack patterns, bar yielding and ultimate strengths. Secondly, since the calculations of both the main bar strain distribution and the ultimate column capacities are based on the same model, the proposed classification method acts as a support to the validity of the use of the truss and arch mechanisms in the determination of the ultimate strengths of reinforced concrete columns. Lastly, the proposed approach could give a better evaluation of the ultimate capacity of the column, whether shear, bond splitting or flexure, and could serve as an aid in the improvement of the design equations found in building codes.

\section{TRUSS AND ARCH MODEL THEORY}

Predicting resulting failure modes is very essential in the design of columns to assure safety and adequate resistance to earthquake forces. Although there are existing equations regarding the shear, bond splitting and flexural capacities of columns, results showed some inconsistencies with regard to the theoretical and experimental values as well as the observed crack patterns and reinforcing bar strains. The truss and arch mechanisms were used in the calculations involving the shear and bond splitting capacities of columns while the ultimate strength concept was applied for the flexural capacities wherein the concrete stresses were represented by the e-function distri- bution while the steel stresses by a bilinear elastic-perfectly plastic distribution. Moreover, a comparison of the theoretical strain distribution to the experimental strain distribution in the main reinforcement based on each of the failure modes was done. The truss and arch model was also used in the calculations of the theoretical strains for the shear and bond splitting types while the equilibrium and strain compatibility assumptions were used for the flexural type. Finally, failure mode classification was performed using the data gathered.

\subsection{Column Capacity}

Failure of a column depends on its overall strength. Since the column could fail in either shear, bond splitting or flexure, the lateral force capacities according to the various failure modes were determined.

(1) Shear

The shear capacity of columns was calculated by the strength equation given in the design code of the Architectural Institute of Japan ${ }^{1)}$ which is as shown in Eq. (1).

$$
\begin{aligned}
Q_{s u} & =Q_{s u t}+Q_{\text {sua }} \\
& =b j_{t} p_{w} \sigma_{w y} \cot \phi+\tan \theta(1-\beta) b D \nu \sigma_{B} / 2
\end{aligned}
$$

This equation is actually based on the truss and arch model theory in structural mechanics wherein the first term is the one contributed by the truss mechanism while the second term by the arch mechanism.

\section{( 2 ) Bond Splitting}

The bond splitting capacity of columns is mainly dependent on the bond strength of the main reinforcement. Among the proposed equations given for the bond strength of bars are those given by Fujii-Morita $^{2), 3)}$ and $\mathrm{Kaku}^{4), 5)}$. These were modified into the SI units and were used in the determination of the bond splitting capacity through the use of the truss and arch model.

The bond strength equation proposed by $\mathrm{Fu}-$ jii-Morita is shown in Eq. (2). The first term shows the concrete contribution while the second term gives that of the steel.

$$
\begin{aligned}
\tau_{b u}= & \left(0.096 b_{i}+0.134\right) \sqrt{\sigma_{B}} \\
& +7.8 k A_{s t} / s N_{t} d_{b} \cdot \sqrt{\sigma_{B}}
\end{aligned}
$$

On the other hand, the bond strength equations 
proposed by Kaku are shown in Eqs. (3) and (4).

$$
\begin{aligned}
\tau_{b u}= & {\left[0.17+0.06 b_{i}+0.31 k_{n}\left(q b_{i}\right.\right.} \\
& \left.\left.+18.2 p_{w} b /\left(N_{t} d_{b}\right)\right)\right] \cdot \sqrt{\sigma_{B}}
\end{aligned}
$$

but when,

$$
\begin{aligned}
p_{w} \sigma_{w y}<0.413 \sqrt{\sigma_{B}} & \\
\tau_{b u}= & {\left[0.42+0.14 b_{i}+0.76 k_{n}\left(q b_{i}\right.\right.} \\
& \left.\left.+18.2 p_{w} b /\left(N_{t} d_{b}\right)\right)\right] \cdot p_{w} \sigma_{w y}
\end{aligned}
$$

In the derivation of the bond splitting capacity, the truss and arch model was also made as the basis of the shear resisting mechanism. The calculated bond strength using the proposed equations was used as the controlling parameter in the derivation of the bond splitting capacity. Accordingly, the bond splitting capacity is given by Eq. (5), which is composed of contributions of both the truss and arch mechanisms.

$$
\begin{aligned}
Q_{b u} & =Q_{b u t}+Q_{b u a} \\
& =\tau_{b u}(\Sigma \psi) j_{t}+\tan \theta(1-\beta) b D \nu \sigma_{B} / 2(5)
\end{aligned}
$$

where,

$\tau_{b u}$ : bond strength of the main reinforcement

$\Sigma \phi:$ summation of the perimeter of the extreme row of main reinforcement

$$
\beta=\left\{\tau_{b u}(\Sigma \phi)\left(1+\cot ^{2} \phi\right)\right\} /\left(b \cot \phi \nu \sigma_{B}\right)
$$

\section{(3) Flexure}

The calculation of the flexural capacity was based on the ultimate strength concept having the following assumptions. First, plane sections before flexure remain plane after flexure. Second, the actual shape of the concrete compression zone is represented by the exhibited stress-strain curve of the concrete based on the e-function model ${ }^{6}$ ) Third, the tensile strength of the concrete is negligible. Fourth, a bilinear elastic-perfectly plastic stress-strain relationship for the main reinforcement is used.

Considering the stress-strain conditions along the column cross-section, the general behavior at the critical portion of a column is that at an increasing lateral load, the strain of the concrete at the extreme compression fiber also increases. Using this concept, an iterative procedure was done wherein values of the strain at the extreme compression fiber were assigned and the corresponding locations of the neutral axis were determined by simple force equilibrium. Having determined the location of the neutral axis, the corresponding values of the lateral load, $Q$, can be calculated by moment equilibrium. From the foregoing procedure, a relationship between the lateral load and the location of the neutral axis as a function of the concrete strain on the extreme compression fiber can be derived. Therefore, the flexural capacity, $Q_{m u}$, of the column corresponds to the maximum calculated value obtained from the above procedure.

\subsection{Effect of Axial Loading}

In the aforementioned discussion of the column capacity based on the truss and arch model, the loading condition on a regular beam where axial loading is not applied is considered. However, for columns, the level of axial loading is relatively high and has a considerable effect on its overall behavior.

Figure 1 (a) shows a schematic diagram of the behavior of the column having an axial load, $N$ $(>0)$, when subjected to lateral seismic forces. It is shown that a concrete arch will be formed along the diagonal of the column ${ }^{7)}$ that would partly resist the axial load applied and the remaining of which would be carried by the main reinforcement. Moreover, from equilibrium, it was derived that the lateral force due to the applied axial load, Qaxial, is resisted solely by the concrete arch and is given by Eq. (6).

$$
Q_{a x i a l}=\sigma_{a x i a l} b x^{\prime} \cos \theta^{\prime} \sin \theta^{\prime}
$$

where,

$\sigma_{\text {axial }}:$ concrete arch stress due to axial action $x^{\prime}:$ depth of the concrete arch due to axial action

$\theta^{\prime}$ : angle of the concrete arch due to axial

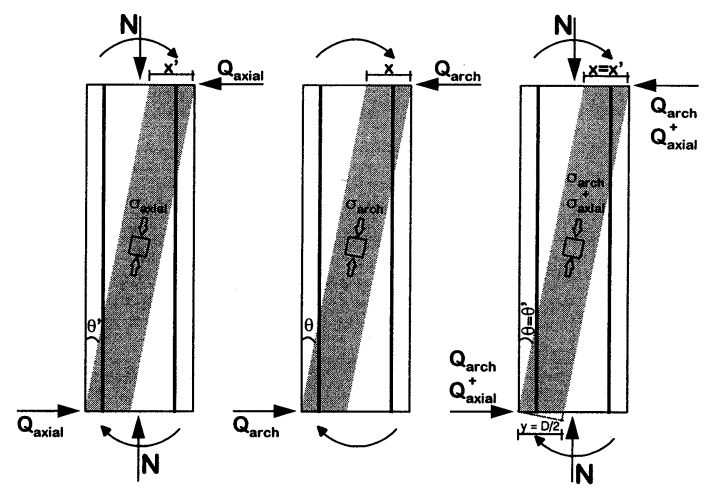
a) axial action
b) arch action
c) combined

Fig. 1 Effect of Axial Loading 
action

Such analogy is very similar to the diagram representing the column behavior due to the arch mechanism as shown in Fig. 1 (b) except for the presence of axial loading. For this case, the lateral force, $Q_{a r c h}$, is also resisted solely by the concrete arch as shown in Eq. (7).

$$
Q_{a r c h}=\sigma_{a r c h} b x \cos \theta \sin \theta
$$

where,

$\sigma_{\text {arch }}:$ concrete arch stress due to arch action

$x:$ depth of the concrete arch due to arch action

$\theta$ : angle of the concrete arch due to arch action

In order to maximize the lateral force contribution due to the arch mechanism and the axial load, both diagrams are combined as shown in Fig. 1 (c) wherein the stress in the concrete arch is given by $\sigma_{\text {arch }}+\sigma_{\text {axial }}$ and the resulting lateral force is $Q_{a r c h}+Q_{a x i a l}$. From the figure, the depth and angle of the concrete arch for both the axial and arch actions are assumed to be identical. By a similar procedure as in the arch mechanism, the lateral force due to both actions is shown by Eq. (8).

$$
Q_{a r c h}+Q_{a x i a l}=\left(\sigma_{a r c h}+\sigma_{\text {axial }}\right) b D \tan \theta / 2
$$

However, the stress in the concrete arch can be equated to the remaining concrete capacity after considering the stress carried by the truss mechanism $\left(\sigma_{\text {arch }}+\sigma_{\text {axial }}=\nu \sigma_{B}-\sigma_{\text {truss }}\right)$. Therefore,

$$
Q_{\text {arch }}+Q_{\text {axial }}=\left(\nu \sigma_{B}-\sigma_{\text {truss }}\right) b D \tan \theta / 2
$$

where,

$\sigma_{\text {truss }}$ : concrete strut stress due to truss action

Equation (9) shows that the total lateral force due to the arch mechanism and the axial load is equivalent to the lateral force contribution due to pure arch action given in Eqs. (1) and (5) for shear and bond splitting types, respectively. It is implied that even though the axial load provides an additional contribution to the lateral force capacity, it actually causes a corresponding decrease in the pure arch action contribution. Thus, it is concluded that the presence of axial loading has no apparent effect on the previously calculated lateral force contribution due to the arch mechanism, but it has a strong influence on the straining of the main bars.
For the case of Eq. (9) being zero, it is assumed that the stress in the concrete struts due to the truss action is equal to the effective compressive strength of the concrete. Moreover, the full carrying capacity of the concrete is already exhausted and that the arch mechanism cannot develop. Therefore, for this case, the axial load is solely resisted by the main bars.

\subsection{Strain Distribution in the Main Reinforce- ment}

The application of the truss and arch model in the determination of the strain distribution in the main reinforcement is considered. For this section, only the distributions for the shear and bond splitting failure modes are dealt with. In this two cases, the level of straining in the main bars remains on the elastic range that, even though the bars are stressed under repeated cyclic loading, their behavior seems to be similar to that subjected to monotonic loading.

In the truss mechanism, the value of the strain is determined using the calculated force on the main bar based on the equilibrium of the infinitesimal stringer elements. Since the column is loaded under double bending, it is considered as point symmetric at the center of the column. Hence, from the free body diagram shown in Fig. 2 , since there is no vertical load for the truss mechanism $\left(\mathrm{F}_{1}+\mathrm{F}_{2}=0\right)$ and that the stress condition at the both points in the main reinforcement lying on a plane inclined at an angle $\phi$ passing through the center of the column is the same $\left(\mathrm{F}_{1}=\right.$

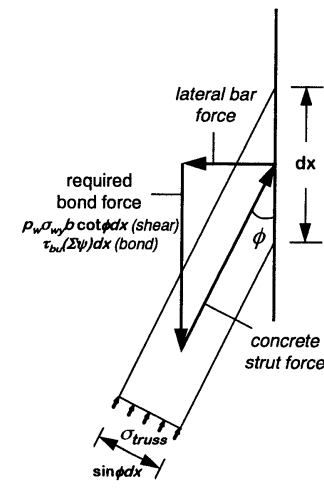

a) stringer element

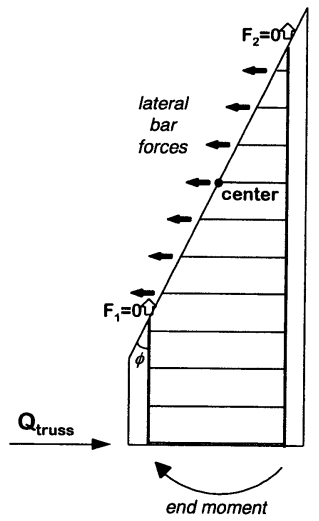

b) line of zero strain
Fig. 2 Equilibrium Conditions 
$\left.\mathrm{F}_{2}\right)$, it can be shown that the strain is zero $\left(\mathrm{F}_{1}=\mathrm{F}_{2}\right.$ $=0$ ) at those same points in the main reinforcement. Since the force on the main bar is associated with stresses due to bond, it is directly dependent on the distance from the point of zero strain. Therefore, the resulting bond forces on the main bars for both the shear and bond splitting failure modes are represented by Eqs. (10) and (11).

bond force $=p_{w} \sigma_{w y} b \cot \phi l_{x} \quad$ (shear type)

bond force $=\tau_{b u} \Sigma \phi l_{x} \quad$ (bond splitting type)

where,

$l_{x}$ : distance from the point of zero strain

By converting the force to strain, the strain distribution due to the truss action in terms of the calculated capacity, $Q_{t r u s s}$, is given by Eq. (12).

$$
\varepsilon_{\text {truss }}=\frac{Q_{\text {truss }} l_{x}}{j_{t} a_{r} E}
$$

where,

$$
\begin{aligned}
Q_{\text {truss }} & =Q_{\text {sut }}(\text { shear type }) \\
& =Q_{b u t}(\text { bond splitting type })
\end{aligned}
$$

$a_{r}$ : total cross-sectional area of the extreme row of the main reinforcement

$E$ : Young's modulus of the main reinforcement

A diagram showing the strain distribution due to the truss mechanism is provided in Fig. 3.

Next, the effect of axial loading will be incorporated into the derivation of the strain distribution on the main reinforcement due to the arch mechanism. From Fig. 4 and by simple equilibrium of
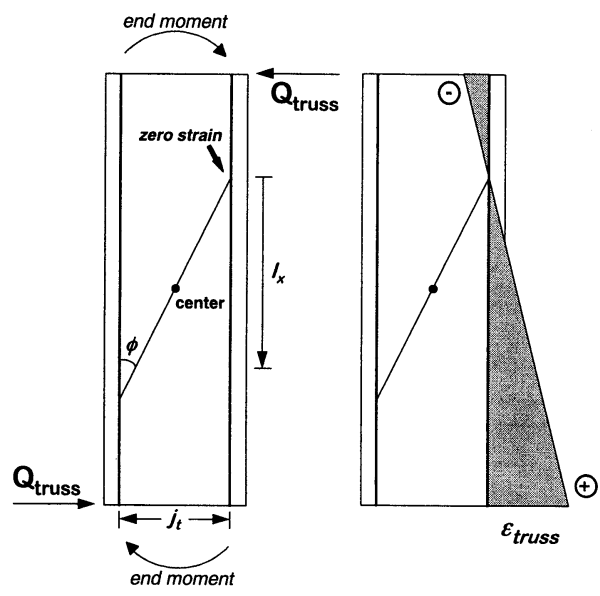

a) truss action

b) strain distribution

Fig. 3 Truss Mechanism

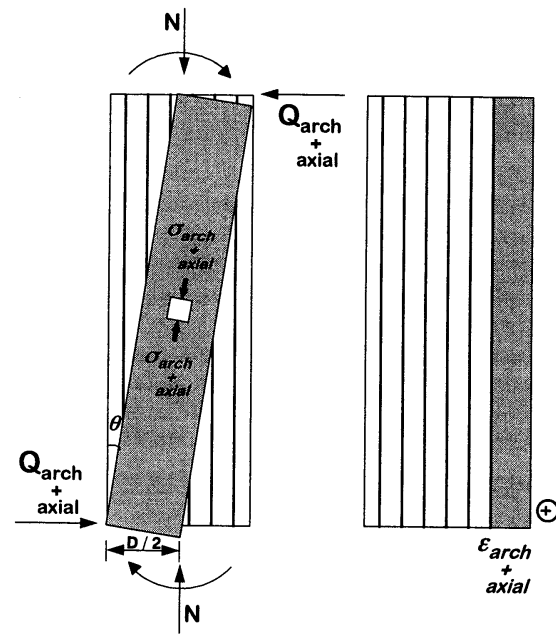

a) arch and axial action b) strain distribution

Fig. 4 Arch Mechanism and Axial Loading

forces, the axial load is resisted by both the concrete arch and the main reinforcement. Using the remaining compressive stress of the concrete for the arch mechanism with axial action, $\sigma_{\text {archtaxial }}$, the compressive force in the concrete arch is given by Eq. (13).

$$
\text { compressive force }=\frac{\sigma_{a r c h+a x i a l} b D / 2}{\cos \theta}
$$

By equilibrium, the resultant of the forces on all of the main bars is given by Eq. (14).

$$
\text { bar force }=\sigma_{\text {arch }+a x i a l} b D / 2-N
$$

Therefore, the strain due to the arch action with proper consideration of axial loading in terms of the calculated capacity, Qarchtaxial, is given by Eq. (15).

$$
\varepsilon_{\text {arch }+ \text { axial }}=\frac{\frac{Q_{\text {arch }+ \text { axial }}}{\tan \theta}-N}{a_{g} E}
$$

where,

$$
\begin{aligned}
Q_{\text {arch }+ \text { axial }} & =Q_{\text {sua }}(\text { shear type }) \\
& =Q_{\text {bua }}(\text { bond splitting type })
\end{aligned}
$$

$a_{g}$ : total cross sectional area of all the main bars

$N$ : axial load (+for compression)

A diagram showing the strain distribution due to the arch mechanism and the effect of axial loading is provided in Fig. 4.

To summarize, the strain distribution on the extreme main bars is determined by Eq. (16).

$$
\varepsilon=\varepsilon_{\text {truss }}+\varepsilon_{\text {arch }+ \text { axial }}
$$




\section{EXPERIMENT DETAILS}

\subsection{Specimen}

For convenience in the discussion to follow, the outline and cross sectional details of the specimens as well as the column specifications were reproduced in Fig. 5 and Table 1. Recently, considerable experimental researches on reinforced concrete columns have been directed towards better evaluation of the ultimate strength as influenced by a number of parameters. Experiments done by Kobayashi et $a l^{8)}$ and Alcantara et $a l^{9) \sim 11)}$ focused on the shear and bond splitting capacities of $\mathrm{RC}$ columns with the lateral reinforcement ratio, yield strength of the lateral hoops and concrete strength being varied. Additional results from tests done by Nomoto et $a l^{12}$ ) which studied the flexural failure of RC columns, have supplement-

Table 1 Column Specifications

\begin{tabular}{|c|c|c|c|c|c|c|c|c|c|c|c|c|}
\hline \multirow{2}{*}{$\begin{array}{c}\text { Speci- } \\
\text { men }\end{array}$} & \multirow{2}{*}{$\begin{array}{l}\text { Casting } \\
\text { Method }\end{array}$} & \multirow{2}{*}{$\begin{array}{c}\text { Column } \\
\text { Dimensions } \\
\mathrm{b} \times \mathrm{D} \times \mathrm{L}\end{array}$} & \multicolumn{2}{|c|}{ Lateral Reinforcement } & \multirow{2}{*}{$\begin{array}{c}P_{w} \\
\%\end{array}$} & \multirow{2}{*}{$\begin{array}{l}\text { Main } \\
\text { Bars }\end{array}$} & \multirow{2}{*}{$\begin{array}{c}\text { Sheath } \\
\text { Diameter } \\
\text { (PCa) }\end{array}$} & \multirow{2}{*}{$\begin{array}{l}\text { Lapping } \\
\text { Bars } \\
\text { (PCa) }\end{array}$} & \multirow{2}{*}{$\begin{array}{l}\text { Concrete } \\
\text { Strength } \\
\sigma_{B}, \mathrm{MPa}\end{array}$} & \multirow{2}{*}{$\begin{array}{l}\text { Axial } \\
\text { Load }\end{array}$} & \multirow{2}{*}{$\begin{array}{c}\text { Ultimate } \\
\text { Strength } \\
(\mathrm{kN})\end{array}$} & \multirow{2}{*}{$\begin{array}{l}\text { Failure } \\
\text { Mode }\end{array}$} \\
\hline & & & Amount & Strength & & & & & & & & \\
\hline \multirow{8}{*}{$\begin{array}{l}\text { RC 21 } \\
\text { PC } 22 \\
\text { PC } 23 \\
\text { PC } 24 \\
\text { PC } 25 \\
\text { PC } 26 \\
\text { PC } 27 \\
\text { PC } 28\end{array}$} & $\mathrm{RC}$ & \multirow{8}{*}{$\begin{array}{c}500 \times 500 \\
\times 1200\end{array}$} & 4-D 10@100 & \multirow{8}{*}{ SD $295 \mathrm{~A}$} & \multirow{8}{*}{$\begin{array}{l}0.57 \\
0.57 \\
0.29 \\
0.57 \\
0.77 \\
0.29 \\
0.57 \\
0.77\end{array}$} & \multirow{8}{*}{$\begin{array}{l}16-\mathrm{D} 22 \\
(\mathrm{SD} 345)\end{array}$} & \multirow[t]{2}{*}{ none } & \multirow[t]{2}{*}{ none } & & & 1067 & $\mathrm{~S}$ \\
\hline & \multirow{7}{*}{$\mathrm{PCa}$} & & 4-D 10@100 & & & & & & & & 1040 & $\mathrm{~S}$ \\
\hline & & & 2-D 10@100 & & & & & & & $0.1 \sigma_{B}$ & 756 & $\mathrm{Bo} \rightarrow \mathrm{S}$ \\
\hline & & & 4-D 10@100 & & & & & D 16 & 30 & & 1024 & $\mathrm{~S}$ \\
\hline & & & $4+\sqrt{2}-\mathrm{D} 10 @ 100$ & & & & $34 \mathrm{~mm}$ & (SD 345) & ou & & 1120 & $\mathrm{~F} \rightarrow \mathrm{S}$ \\
\hline & & & 2-D 10@100 & & & & & & & & 780 & $\mathrm{Bo} \rightarrow \mathrm{S}$ \\
\hline & & & 4-D 10@100 & & & & & $d_{L}=16 \mathrm{~mm}$ & & $0.2 \sigma_{B}$ & 1142 & $\mathrm{~S}$ \\
\hline & & & $4+\sqrt{2}-\mathrm{D} 10 @ 100$ & & & & & & & & 1220 & $\mathrm{~F} \rightarrow \mathrm{S}$ \\
\hline C $31 \mathrm{P}$ & & & 6-D 10@150 & & 0.63 & & & & & & 919 & $\mathrm{~S} \rightarrow \mathrm{Bo}$ \\
\hline C $32 \mathrm{P}$ & & & 6-D 10@120 & & 0.79 & & & D 16 & & & 1040 & $\mathrm{~S} \rightarrow \mathrm{Bo}$ \\
\hline C $33 \mathrm{P}$ & $\mathrm{PCa}$ & & 6-D 10@100 & & 0.95 & & $34 \mathrm{~mm}$ & (SD 685) & & & 1129 & $\mathrm{~S} \rightarrow \mathrm{Bo}$ \\
\hline C $34 \mathrm{P}$ & & $450 \times 450$ & 6-D 10@80 & $\mathrm{SD} 295 \mathrm{~A}$ & 1.19 & $20-\mathrm{D} 22$ & & $d_{L}=16 \mathrm{~mm}$ & 30 & $0.2 \sigma_{B}$ & 1258 & $\mathrm{~S} \rightarrow \mathrm{Bo}$ \\
\hline C $35 \mathrm{P}$ & & $\times 1350$ & 6-D 10@65 & & 1.46 & (SD 685) & & & & & 1303 & $\mathrm{~S} \rightarrow \mathrm{Bo}$ \\
\hline C $31 \mathrm{M}$ & & & 6-D 10@150 & & 0.63 & & & & & & 799 & $\mathrm{~S} \rightarrow \mathrm{Bo}$ \\
\hline C $33 \mathrm{M}$ & $\mathrm{RC}$ & & 6-D 10@100 & & 0.95 & & none & none & & & 997 & $\mathrm{~S} \rightarrow \mathrm{Bo}$ \\
\hline C $35 \mathrm{M}$ & & & 6-D 10@65 & & 1.46 & & & & & & 1163 & $\mathrm{~S} \rightarrow \mathrm{Bo}$ \\
\hline C $41 \mathrm{P}$ & & & & & & & & & & $0.25 \sigma_{B}$ & 536 & F \\
\hline C $42 \mathrm{P}$ & & & & & & & & D 13 & & $0.2 \sigma_{B}$ & 517 & $\mathrm{~F}$ \\
\hline C $43 \mathrm{P}$ & $\mathrm{PCa}$ & & & & & & $30 \mathrm{~mm}$ & (SD 345) & & $0.1 \sigma_{B}$ & 463 & $\mathrm{~F}$ \\
\hline C $44 \mathrm{P}$ & & $450 \times 450$ & 6-D 10@100 & SD $295 \mathrm{~A}$ & 0.95 & $20-\mathrm{D} 16$ & & $d_{L}=13 \mathrm{~mm}$ & 33 & 0 & 388 & $\mathrm{~F}$ \\
\hline C $45 \mathrm{P}$ & & $\times 2000$ & & & & (SD 390) & & & & $-0.1 \sigma_{B}$ & 305 & $\mathrm{~F}$ \\
\hline C $41 \mathrm{M}$ & & & & & & & & & & $0.25 \sigma_{B}$ & 533 & $\mathrm{~F}$ \\
\hline C $43 \mathrm{M}$ & $\mathrm{RC}$ & & & & & & none & none & & $0.1 \sigma_{B}$ & 439 & $\mathrm{~F}$ \\
\hline $\mathrm{C} 45 \mathrm{M}$ & & & & & & & & & & $-0.1 \sigma_{B}$ & 292 & $\mathrm{~F}$ \\
\hline C $51 \mathrm{P}$ & & & 2-D 10@100 & & 0.32 & & & & & & 646 & Bo \\
\hline C $52 \mathrm{P}$ & & & 4-D 10@100 & SD 785 & 0.63 & & & & & & 1057 & Bo \\
\hline C $53 \mathrm{P}$ & $\mathrm{PCa}$ & & 6-D 10@80 & & 1.19 & & $34 \mathrm{~mm}$ & & & & 1494 & $\mathrm{~F} \rightarrow \mathrm{Bo}$ \\
\hline C $54 \mathrm{P}$ & & & 2-U 9@100 & & 0.28 & & & & & & 648 & Bo \\
\hline C $55 \mathrm{P}$ & & $450 \times 450$ & 4-U 9@100 & USD 1275 & 0.57 & $20-\mathrm{D} 22$ & & none & 39 & $0.15 \sigma_{B}$ & 1019 & Bo \\
\hline C $56 \mathrm{P}$ & & $\times 1350$ & 6-U9@80 & & 1.07 & (SD 685) & & & & & 1567 & $\mathrm{~F} \rightarrow \mathrm{Bo}$ \\
\hline C $51 \mathrm{M}$ & & & 2-D 10@100 & SD 785 & 0.32 & & & & & & 653 & Bo \\
\hline C $53 \mathrm{M}$ & $\mathrm{RC}$ & & 6-D 10@80 & & 1.19 & & none & & & & 1437 & $\mathrm{~F} \rightarrow \mathrm{Bo}$ \\
\hline C $54 \mathrm{M}$ & & & 2-U99100 & USD 1275 & 0.28 & & & & & & 639 & Bo \\
\hline C $56 \mathrm{M}$ & & & 6-U 9@80 & & 1.07 & & & & & & 1451 & $\mathrm{~F} \rightarrow \mathrm{Bo}$ \\
\hline C $61 \mathrm{M}$ & $\mathrm{RC}$ & & 4-D 10@150 & & 0.42 & & none & & & & 770 & $\mathrm{Bo} \rightarrow \mathrm{S}$ \\
\hline C $61 \mathrm{P}$ & & & 4-D 10@150 & & 0.42 & & & & 37 & $0.31 \sigma_{B}$ & 853 & $\mathrm{~S} \rightarrow \mathrm{Bo}$ \\
\hline C $62 \mathrm{P}$ & & & 6-D 10@120 & & 0.79 & & & & & & -1033 & $\mathrm{~S} / \mathrm{Bo}$ \\
\hline $\mathrm{C} 63 \mathrm{P}$ & & & 6-D 10@80 & & 1.19 & & & & & & 1333 & S/Bo \\
\hline C 64 P & $\mathrm{PCa}$ & $450 \times 450$ & 4-D 10@150 & SD $295 \mathrm{~A}$ & 0.42 & $20-\mathrm{D} 22$ & $34 \mathrm{~mm}$ & none & & & 1081 & $\mathrm{~S} \rightarrow \mathrm{Bo}$ \\
\hline C $65 \mathrm{P}$ & & $\times 1350$ & 2-D 10@75 & & 0.42 & (SD 685) & & & & & 1008 & S/Bo \\
\hline C 66 P & & & 6-D 10@120 & & 0.79 & & & & 70 & $0.23 \sigma_{B}$ & 1347 & $\mathrm{~S} \rightarrow \mathrm{Bo}$ \\
\hline C $67 \mathrm{P}$ & & & $4-\mathrm{D} 10 @ 80$ & & 0.79 & & & & & & 1300 & S/Bo \\
\hline C $68 \mathrm{P}$ & & & 6-D 10@80 & & 1.19 & & & & & & 1618 & $\mathrm{~S} \rightarrow \mathrm{Bo}$ \\
\hline $\mathrm{C} 68 \mathrm{M}$ & $\mathrm{RC}$ & & 6-D 10@80 & & 1.19 & & none & & & & 1611 & S/Bo \\
\hline
\end{tabular}

RC: monolithic PCa: precast concrete S: shear Bo: Bond Splitting F : Flexure

$\rightarrow$ : subsequent occurrence $/$ : coincident occurrence 

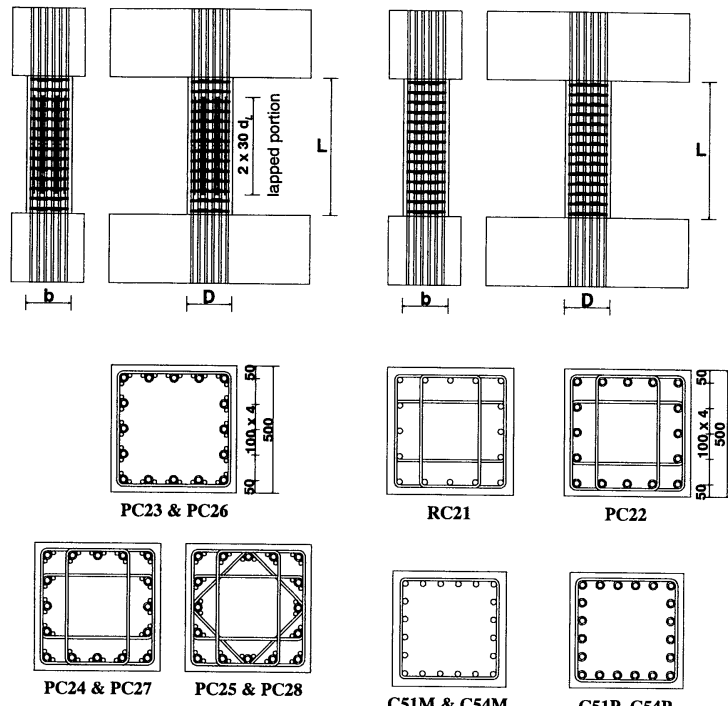

C51M \& C54M
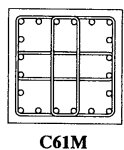

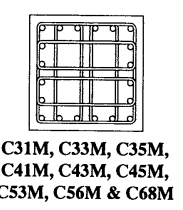

31P, C32P, C33P,

C34P, C35P, C41P, C42P, C43P, C44P \& C45P

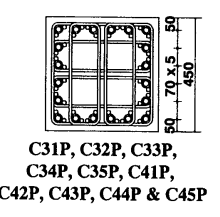

a) specimens with lapping bars b) specimens without lapping bars

Fig. 5 Outline and Cross Sections of the Specimens

ed this analysis. It should also be noted that the precast concrete specimens were constructed using the main bar post-insertion system ${ }^{13}$ ). As for the precast concrete specimens grouped in Fig. 5 (b), instead of using upper and lower bars, continuous main reinforcement were used to further evaluate the seismic performance of the spiral steel sheaths.

The main bar post-insertion system is described as the process wherein at the factory, the precast concrete members are prefabricated without the presence of the main bars, and later at the construction site, the main bars are inserted and abutted at the middle portion of each member where the stresses due to seismic forces are small. This type of joint features the use of spiral steel sheaths which are hollow tubes positioned in place of the main bars in precast concrete members wherein such bars are to be later inserted during assembly. For this connection system, lapping bars are positioned alongside main bar abutments to allow for adequate force transfer.

Since in most of the precast concrete specimens, spiral steel sheaths as well as lapping bars alongside of the main reinforcement were used, it is necessary to show that such a system behaves in a similar manner as ordinary reinforcing bars especially with regard to the bond splitting mechanism produced under loading. It was shown in previous researches involving the bond splitting strengths of sheaths ${ }^{14)}$ that failure occurred around the perimeter of the sheath and that the sheath-grout-main bar system acts as a unit very much similar to an ordinary deformed bar. Also, the configuration of the spiral steel sheath used in the experiments conforms with the Japan Industrial Standard (JIS G 3112) "Steel Bars for Reinforced Concrete” specifications.

\subsection{Loading System}

Each of the column specimens was set under the loading apparatus shown in Fig. 6. The lateral force was applied through the horizontal actuator while the axial load was provided by the vertical actuators shown. These specimens were subjected to varying shear forces that were applied continuously in a cyclic manner producing anti-symmetric bending moment distribution while being acted upon by a constant axial load. Each column specimen was set using oil jacks found on both sides of the upper and lower beams.

The application of shear forces was controlled by the following loading history. For the proper simulation of seismic behavior, each specimen

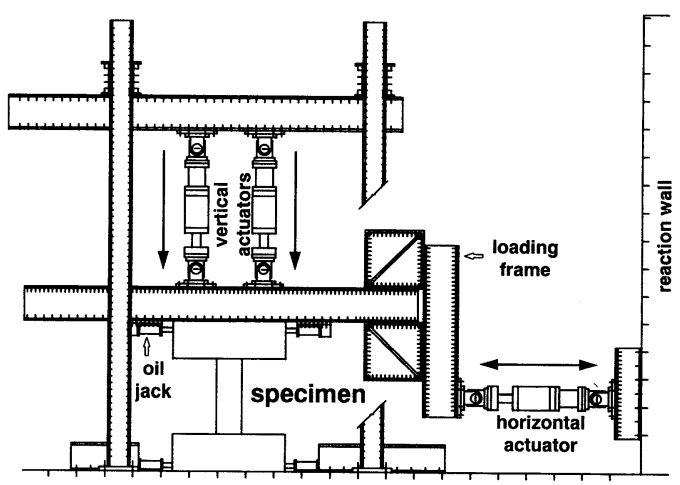

Fig. 6 Loading Apparatus 
was made to displace once at a drift angle $R$ equal to $\pm 1 / 800$, then twice at $R$ of $\pm 1 / 400$, \pm $1 / 200, \pm 1 / 100$ and $\pm 1 / 50$ and again once at $R$ equal to $\pm 1 / 25$. The drift angle is defined as the ratio of the relative displacement of the upper and lower beams to the column height. Moreover, strain gauges were strategically positioned all over the reinforcing bars of the specimen. Representative locations of these gauges are shown in Figs. 7 and 8 .

Main quantitative results that were considered in this analysis are the actual strain in both the main and lateral reinforcement and the ultimate lateral load attained. Besides these, qualitative observations from the resulting crack patterns were considered.

\subsection{Crack Patterns and Bar Strains}

In the determination of the resulting failure mode in an actual scaled experimentation, the most basic method would be to rely on the cracks appearing during the progress of the experiment. The location and orientation of the cracks as well as the crushing of the concrete is of great aid in the task of classifying the type of the resulting failure mode. The following set of photographs shows the typical crack patterns of the different types of failure modes which resulted from the series of experiments performed.

The crack patterns shown in Photo. 1 are presented in the order of the conduction of the experi-

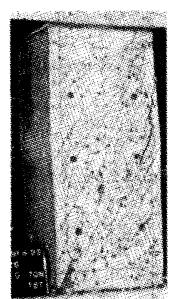

(a) $\mathrm{RC} 21$ [S]

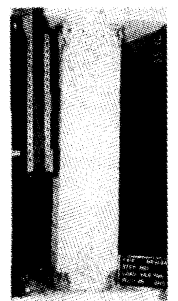

(e) C41P [F]

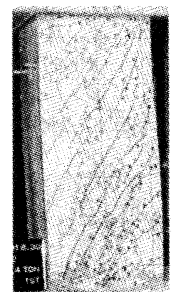

(b) PC24 [S]

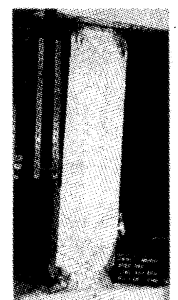

(1) $\mathrm{C} 41 \mathrm{M}[\mathrm{F}]$
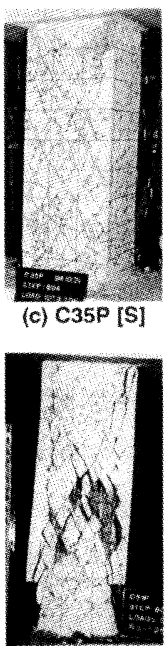

(g) C5tP [Bo]

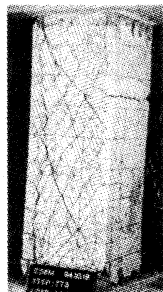

(d) C35M [S]

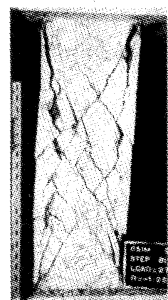

(h) $\mathrm{Cs} 1 \mathrm{M}[\mathrm{Bo}]$
Photo. 1 Typical Crack Patterns ment and for each series, two specimens representing both the monolithic and precast concrete types are given for comparison. The first four pictures, from Photos. 1 (a) to (d), depict the typical shear failure $[\mathrm{S}]$ crack patterns wherein there are a lot of shear cracks produced together with the widening of the cracks at failure. However, bond splitting cracks were observed for the latter two specimens, Photos. 1 (c) and (d), wherein bond splitting failure also commenced after failure in shear. The next two pictures, Photos. 1 (e) and (f), represent the flexural failure [F] type of cracks. The cracks were concentrated at the end portions and crushing of the concrete eventually occurred as typical of a flexural failure. The last two pictures, Photos. $1(\mathrm{~g})$ and $(\mathrm{h})$, on the other hand, are of the bond splitting failure[Bo] type. It can be seen that the bond splitting cracks along the extreme main bar are very much prominent. Considering the comparison between the monolithically cast specimens to that of the precast concrete type, it is evident from the similarity of the pictures that the cracking behavior of the columns is independent of the casting method applied.

Another aspect which could assist in the determination of the resulting failure mode is the actual strain on the reinforcing bars during maximum or peak loading. First, considering the experimental strain on the lateral reinforcement, it
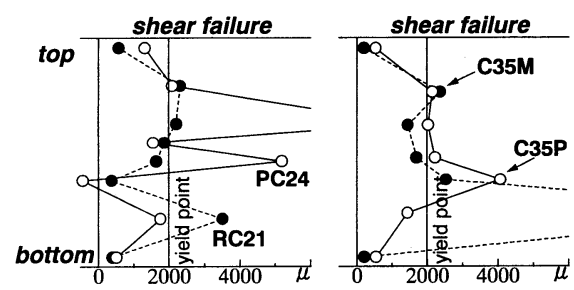

a) yielding type $(R=1 / 50)$

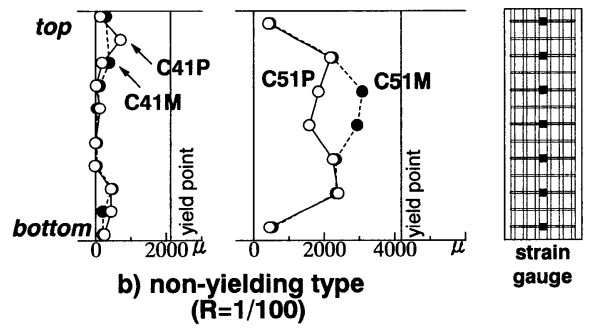

Fig. 7 Strain Distributions in the Lateral Reinforcement at Peak Load 

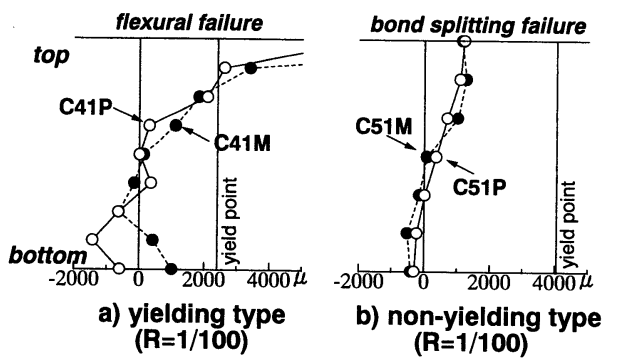

b) non-yielding type ( $R=1 / 100)$

Fig. 8 Strain Distributions in the Main Reinforcement at Peak Load

is typical in shear failure that there is yielding of the lateral reinforcement. From Fig. 7 (a), it can be observed that for the yielding type, there is a good correspondence with the crack patterns of the shear failure type. For the two plots on Fig. 7 (b), it can be seen that there is no yielding of the lateral reinforcement, and hence, those specimens are not failing in shear.

Next, considering the strain in the main bars, failure by flexure is easily identified by the yielding at the end portions. Therefore, by plotting the strain distribution of the main bars of the specimens in Fig. 7 (b), further classification can be done. From Fig. 8 (a), it can be observed that there is yielding of the main bars of specimens $\mathrm{C}$ $41 \mathrm{P}$ and $\mathrm{C} 41 \mathrm{M}$, which suggests a flexural type of failure. This further supports the observed flexural crack patterns during the experiment. Moreover, since there is no yielding of the main bars for the remaining specimens $\mathrm{C} 51 \mathrm{P}$ and $\mathrm{C} 51 \mathrm{M}$, as shown in Fig. 8 (b), those specimens can then be classified as of the bond splitting type.

\section{ANALYSIS ON THE MAIN BAR STRAIN DISTRIBUTION}

Aside from the observed crack patterns and actual bar strains, failure mode classification can also be done through another approach. This is done by an analysis of the state of stress along the main reinforcement. Concepts given in section 2 are utilized and comparisons between the experimental and theoretical strain distributions based on the various failure modes are conducted. The theoretical lines according to both the shear and bond splitting types were derived using the truss and arch model theory with consideration of the effect of axial loading with the assumption that the main bars are in the elastic range. Also, for the bond splitting capacity of precast concrete columns, the diameter of the sheath is used as the working value for the diameter of the main reinforcement. On the other hand, the theoretical distribution according to the flexural failure type is based on simple equilibrium and strain compatibility assumptions on the column cross section to include straining beyond the elastic range. Representative plots according to the resulting failure modes are shown in Fig. 9.

Results show that the actual plot of the experimental strain distribution does not correspond with the theoretical strain distribution based on the observed failure mode for both the shear and bond splitting types. Moreover, the flexural failure type shows a good agreement between the experimentally observed results and the theoretical values on all aspects, namely, ultimate strength, crack patterns and reinforcing bar strains.

Considering the figures individually, it could be observed for PC 23 that the plot of the experimental main bar strain distribution is rather close to the theoretical bond splitting line using the Kaku equation, which is in agreement with the predicted failure mode from ultimate strength calculations, however, a low estimate of the bond splitting capacity was given. For C $31 \mathrm{P}$ and C $31 \mathrm{M}$, the actual plots are distant to the theoretical distributions showing insufficient foundation on determining the resulting failure mode. Also, it can be observed that the actual distributions are closer to the bond splitting failure lines which is again opposed to the experimentally observed failure mode. On the contrary, for C $41 \mathrm{P}$ and C $42 \mathrm{P}$, a generally good agreement was observed. This specimen is of the flexural failure type. However, it can be observed that there is a considerable offset at the end portions, which is mainly due to the value of the strain of a yielded bar subjected to repeated cyclic loading as compared to the theoretically calculated strain based on an increasing monotonic loading. Therefore, the reliable area on the bar is limited to portions that remain under elastic conditions. Moreover, as for $\mathrm{C} 51 \mathrm{P}$ and $\mathrm{C}$ $55 \mathrm{P}$, they are of the bond splitting type and their 


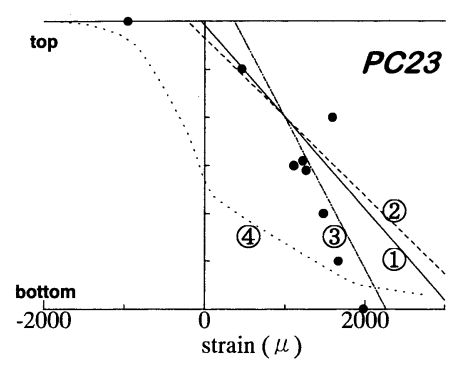

(a) bond splitting failure

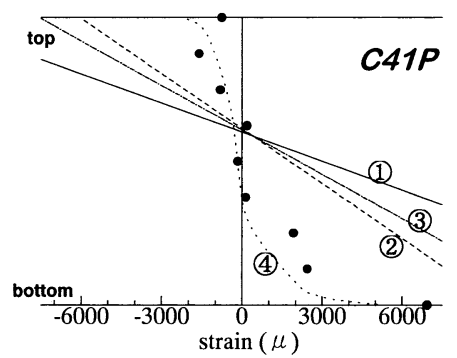

(d) flexural failure

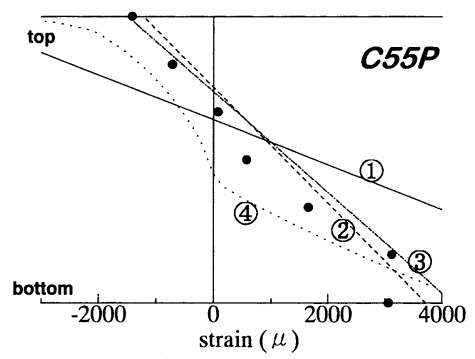

(g) bond splitting failure

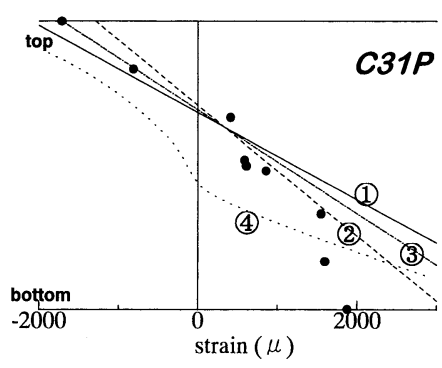

(b) shear failure

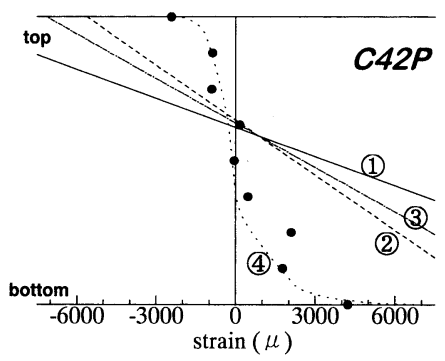

(e) flexural failure

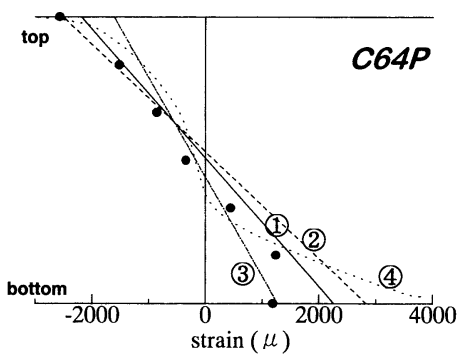

(h) shear failure

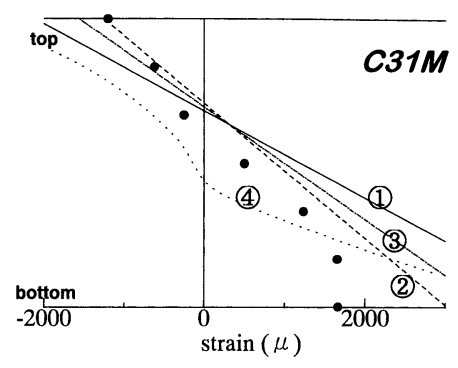

(c) shear failure

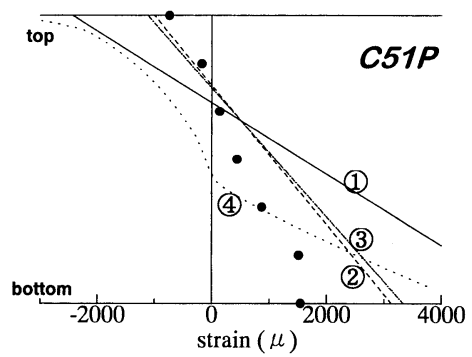

(f) bond splitting failure

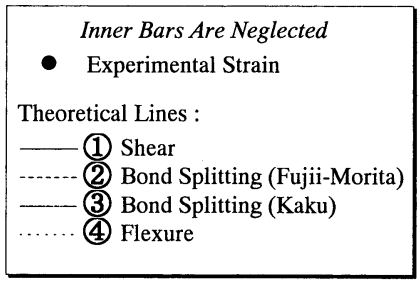

at peak load

Fig. 9 Main Bar Strain Distribution (inner bars are neglected)

experimental strain distributions resemble the bond splitting failure lines but with a considerable offset observed. Finally, for C $64 \mathrm{P}$, results show that the actual plot falls on an area in between the shear and bond splitting failure modes. Also, the actual capacity is very much greater than the calculated values. The main reason for the above inconsistencies is that the presence of inner main bars is not considered in the calculations of both the ultimate strength and the theoretical main bar strain distribution for the shear and bond splitting failure types. On the contrary, the inner main bars are considered in the calculations for the flexural failure type. Therefore, since only the flexural failure type shows good correspondence with regard to all the aspects of determining the resulting failure mode, it is necessary to improve the calculations of the ultimate strengths and the theoretical main bar strain distributions for both the shear and bond splitting types.

\subsection{Effect of Inner Rows of Main Reinforce- ment}

The main difference between the bar arrangement of a column to that of a beam is the presence of the inner rows of main reinforcement. In the previous discussion on the calculation of the bond splitting capacities, only the extreme row of main reinforcement is considered and this accounts for one cause of inconsistency with the observed results. This inconsistency is also observed with regard to the determination of the theoretical strain distribution in the main reinforcement. Therefore, the following modifications are made on both the 
strength and the strain aspects.

Firstly, modifications are done on the calculation of the ultimate strength capacities of the columns. As for the shear strength calculations, since there is no apparent relation between the main reinforcement and the calculated shear capacity, no modifications were made on the shear strength calculations. Thus, only the bond splitting capacity needs modification since the main reinforcement is very much influential in the calculation. The main difference in the calculation is that, instead of using only the extreme row of main reinforcement, additional rows of main bars are included. To simplify, the cross section of the column is divided into two and all the main bars that are located on one half of the cross section is considered in the calculation.

With regard to the equation used in the calculation of the bond splitting capacity, the following adjustment is then made.

$$
\Sigma \phi \rightarrow \Sigma \phi_{h}
$$

where,

$\sum \phi_{h}$ : summation of the perimeter of half of the main reinforcement ( $\mathrm{RC}$ columns) or sheaths (for PCa columns)

The value of $j_{t}$ remains to be the distance between the extreme rows of main reinforcement and the inner rows of main bars are assumed to take their effective positions on the outer row portions. This assumption tends to increase the calculated bond splitting capacities of the columns, which accounts for the underestimation in the original calculations.

The main result of the modification is an increase in the bond splitting capacities of the columns since there is an increase in the number of main bars considered. Quantitatively, calculations show a 20 to 50 percent increase in the calculated bond splitting capacities depending on the column specifications.

Furthermore, in the determination of the theoretical strain distribution in the main reinforcement, it should be noted that only the extreme row was used in the calculation of the strain due to truss mechanism. Therefore, it is also essential that the inner rows be considered in order to have correspondence with the above-mentioned modifi- cation on the calculation of the bond splitting capacity. Hence, the following adjustment in the strain calculation of $\varepsilon_{\text {truss }}$ is made wherein the total cross sectional area of the extreme row of main reinforcement is replaced by the total cross sectional area of half of the main reinforcement.

$$
a_{r} \rightarrow a_{g} / 2
$$

Aside from the bond splitting type, the same modification is also made with regard to the shear failure theoretical line in order to be consistent. Therefore, adjustments on the orientation of the shear and bond splitting theoretical lines would result due to the consideration of the presence of inner main reinforcement. Modifications made on the previous graphs (Fig. 9) considering the effect of the inner rows of main bars are shown in Fig. 10.

From the figures, a generally good correspondence is observed with regard to the predicted and actual resulting failure mode based on the actual plots of the main bar strain distributions especially for Figs. 10 (a) to 10 (e) and $10(\mathrm{~g})$. However, for C $51 \mathrm{P}$ and C $64 \mathrm{P}$ in Figs. 10 (f) and 10 (h), there is a little inaccuracy with the observed results. As for specimen C $51 \mathrm{P}$, although the experimental main bar strain distribution is closer to the predicted failure line, there is a great offset observed. The figure shows that the main bar can still be stressed a little further before failure. However, failure occurred at a lower strain level which proves an overestimation on the calculated bond splitting capacity. It is inferred that the calculated value using the given bond splitting capacity equation is generally overestimated for specimens having a combination of the use of highstrength lateral reinforcement and a low lateral reinforcement ratio. Moreover, for specimen C 64 $\mathrm{P}$, instead of an overestimation, an underestimation on both the calculated shear and bond splitting capacities were observed. This general behavior is typical of high-strength concrete specimens wherein there is a low estimate of the calculated strengths especially for the shear failure mode. Therefore, additional studies are necessary with regard to these aspects.

\subsection{Error Analysis}

Aside from the visual determination of classify- 


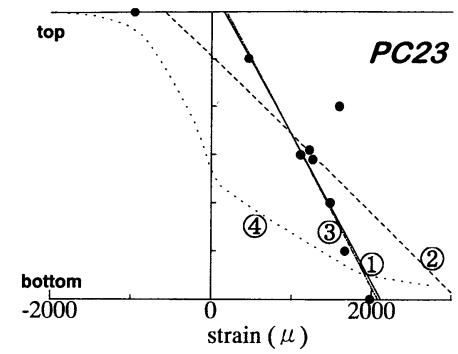

(a) bond splitting failure

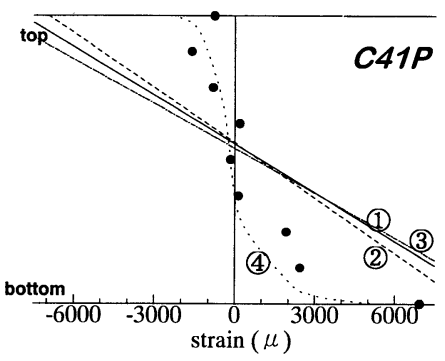

(d) flexural failure

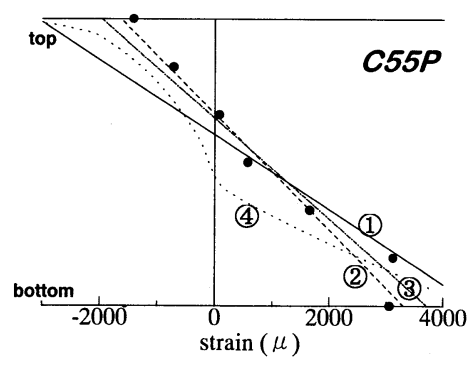

(g) bond splitting failure

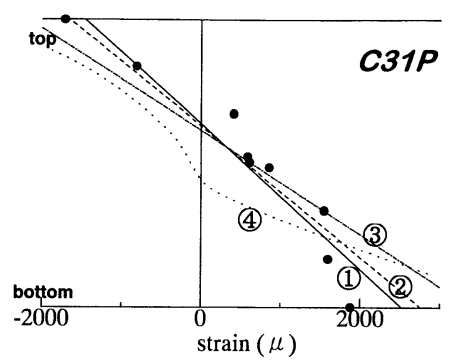

(b) shear failure

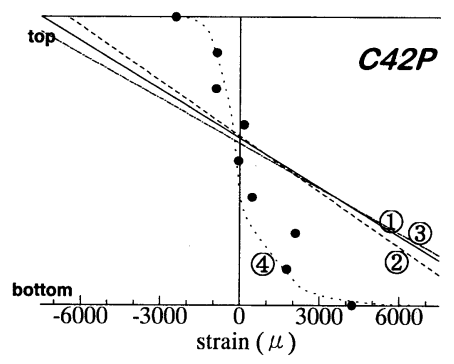

(e) flexural failure

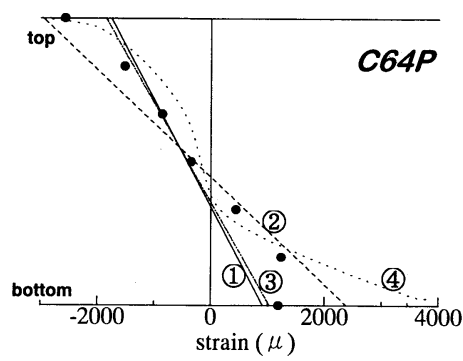

(h) shear failure

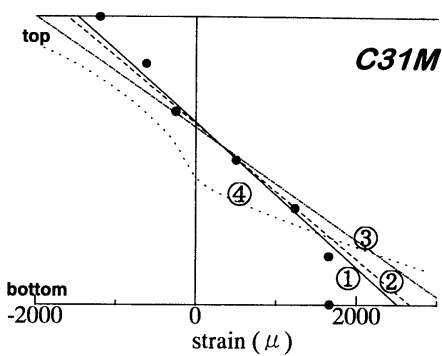

(c) shear failure

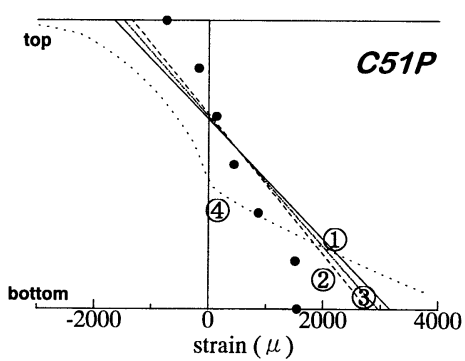

(f) bond splitting failure

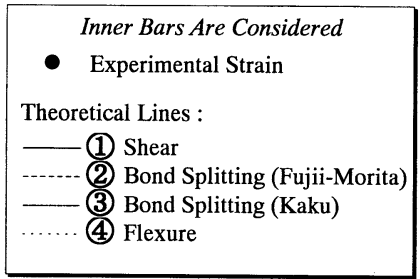

at peak load

Fig. 10 Main Bar Strain Distribution (inner bars are considered)

ing failure modes, a quantitative approach is also possible. A more systematic procedure is presented wherein error estimates between the experimental and theoretical plots are determined and the one showing the least error gives the resulting failure mode. This is more reliable in cases where there is closeness between the theoretical failure lines especially for the shear and bond splitting types. The statistical criteria used is termed the "sum of squares of the errors" or $S S E^{15)}$ and is determined using Fig. 11.

In this procedure, the error is determined by the difference between the experimental strain at a point and the theoretical strain on the failure line at that same point in the main reinforcement. This is done for all points where the actual strains were measured experimentally. These values are

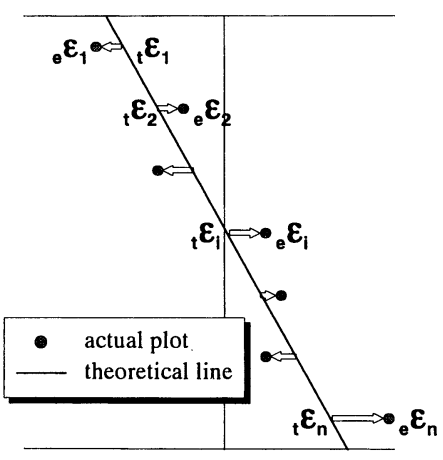

Fig. 11 Error Estimation

then squared to eliminate negative errors. Finally, these values are added to give the SSE. This procedure is summed up in Eq. (19). 


$$
S S E=\sum_{i=1}^{n}\left(e_{i} \varepsilon_{t} \varepsilon_{i}\right)^{2}
$$

where,

$e^{\varepsilon_{i}}$ : experimental strain at the $\mathrm{i}^{\text {th }}$ point in the main reinforcement

${ }_{t} \varepsilon_{i}$ : theoretical strain at the $\mathrm{i}^{\text {th }}$ point

$n$ : total number of measured points

Furthermore, this value can be normalized to an expression showing a percentage error between the experimental and theoretical values as represented by Eqn. (20).

$$
e=\sqrt{\frac{S S E}{\sum_{i=1}^{n}\left({ }_{e} \varepsilon_{i}\right)^{2}}}=\sqrt{\frac{\sum_{i=1}^{n}\left({ }_{e} \varepsilon_{i}-{ }_{t} \varepsilon_{i}\right)^{2}}{\sum_{i=1}^{n}\left({ }_{e} \varepsilon_{i}\right)^{2}}}
$$

The normalized values of the errors, $e$, for all the theoretical failure lines are determined and compared, wherein the least value would show the resulting failure mode. Table 2 gives the calculations made for the specimens considered. For the bond splitting type, only the error estimates for the bond splitting failure line using the Kaku equation are shown, since when considering the specimens featuring a clear bond splitting failure from experimentally observed crack patterns and bar strains, much lesser values of the error are given by the Kaku equation, which shows better precision than the Fujii-Morita equation.

From Table 2, by considering the least among the error estimates from the different failure modes (written in bold numbers), a general agreement between the observed or actual failure mode and the theoretical failure mode is observed. Of the 44 specimens considered, good correspondence between the actual and theoretical failure modes is observed for the 43 specimens (as shown in the remarks column). This shows a high level of precision of the proposed alternative approach in classifying failure modes.

An error estimate of around 0.5 for the theoretical failure mode gives a very good correspondence with the actual failure mode. On the contrary, greater error estimates show an actual main bar strain distribution which is rather distant from the calculated failure line. This implies either an underestimation or overestimation on the theoretical ultimate strength of the column as shown by

\begin{tabular}{|c|c|c|c|c|c|c|}
\hline \multirow{2}{*}{$\begin{array}{c}\text { Speci- } \\
\text { men }\end{array}$} & \multicolumn{3}{|c|}{ Error Estimates $(e)$} & \multirow{2}{*}{$\begin{array}{c}\text { Theoretical } \\
\text { Failure } \\
\text { Mode }\end{array}$} & \multirow{2}{*}{$\begin{array}{c}\text { Actual } \\
\text { Failure } \\
\text { Mode }\end{array}$} & \multirow[b]{2}{*}{ Remarks } \\
\hline & Shear & $\begin{array}{c}\text { Bond } \\
\text { Splitting }\end{array}$ & Flexure & & & \\
\hline $\mathrm{RC} 21$ & 0.30 & 0.39 & 1.55 & $\mathrm{~S}$ & $\mathrm{~S}$ & $\mathrm{OK}$ \\
\hline PC 22 & 0.24 & 0.29 & 1.28 & $\mathrm{~S}$ & $\mathrm{~S}$ & $\mathrm{OK}$ \\
\hline PC 23 & 0.37 & 0.37 & 1.93 & S/Bo & Bo & $\mathrm{OK}$ \\
\hline PC 24 & 0.41 & 0.56 & 1.76 & $\mathrm{~S}$ & $\mathrm{~S}$ & $\mathrm{OK}$ \\
\hline PC 25 & 0.49 & 0.47 & 0.27 & $\mathrm{~F}$ & $\mathrm{~F}$ & $\mathrm{OK}$ \\
\hline PC 26 & 0.59 & 0.59 & 2.42 & S/Bo & Bo & OK \\
\hline PC 27 & 0.12 & 0.21 & 0.80 & $\mathrm{~S}$ & $\mathrm{~S}$ & $\mathrm{OK}$ \\
\hline PC 28 & 0.49 & 0.47 & 0.20 & $\mathrm{~F}$ & $\mathrm{~F}$ & $\mathrm{OK}$ \\
\hline $\mathrm{C} 31 \mathrm{P}$ & 0.28 & 0.56 & 1.45 & $\mathrm{~S}$ & $\mathrm{~S}$ & $\mathrm{OK}$ \\
\hline C $32 \mathrm{P}$ & 0.29 & 0.48 & 1.16 & $\mathrm{~S}$ & $\mathrm{~S}$ & OK \\
\hline $\mathrm{C} 33 \mathrm{P}$ & 0.23 & 0.33 & 0.83 & $\mathrm{~S}$ & $\mathrm{~S}$ & $\mathrm{OK}$ \\
\hline C $34 \mathrm{P}$ & 0.23 & 0.34 & 0.62 & $\mathrm{~S}$ & $\mathrm{~S}$ & $\mathrm{OK}$ \\
\hline $\mathrm{C} 35 \mathrm{P}$ & 0.24 & 0.29 & 0.38 & $\mathrm{~S}$ & $\mathrm{~S}$ & $\mathrm{OK}$ \\
\hline C $31 \mathrm{M}$ & 0.31 & 0.62 & 1.77 & $\mathrm{~S}$ & $\mathrm{~S}$ & $\mathrm{OK}$ \\
\hline C $33 \mathrm{M}$ & 0.43 & 0.53 & 1.24 & $\mathrm{~S}$ & $\mathrm{~S}$ & $\mathrm{OK}$ \\
\hline C $35 \mathrm{M}$ & 0.36 & 0.52 & 0.84 & $\mathrm{~S}$ & $\mathrm{~S}$ & $\mathrm{OK}$ \\
\hline C $41 \mathrm{P}$ & 2.42 & 2.68 & 0.51 & $\mathrm{~F}$ & $\mathrm{~F}$ & OK \\
\hline C $42 \mathrm{P}$ & 3.10 & 3.39 & 0.55 & $\mathrm{~F}$ & $\mathrm{~F}$ & $\mathrm{OK}$ \\
\hline C $43 \mathrm{P}$ & 2.02 & 2.18 & 0.52 & $\mathrm{~F}$ & $\mathrm{~F}$ & $\mathrm{OK}$ \\
\hline $\mathrm{C} 44 \mathrm{P}$ & 1.38 & 1.47 & 0.55 & $\mathrm{~F}$ & $\mathrm{~F}$ & OK \\
\hline $\mathrm{C} 45 \mathrm{P}$ & 2.01 & 2.10 & 0.63 & $\mathrm{~F}$ & $\mathrm{~F}$ & $\mathrm{OK}$ \\
\hline C $41 \mathrm{M}$ & 2.42 & 2.44 & 0.48 & $\mathrm{~F}$ & $\mathrm{~F}$ & OK \\
\hline $\mathrm{C} 43 \mathrm{M}$ & 3.06 & 2.97 & 0.69 & $\mathrm{~F}$ & $\mathrm{~F}$ & $\mathrm{OK}$ \\
\hline $\mathrm{C} 45 \mathrm{M}$ & 3.83 & 3.75 & 1.97 & $\mathrm{~F}$ & $\mathrm{~F}$ & OK \\
\hline C $51 \mathrm{P}$ & 0.92 & 0.79 & 2.91 & Bo & Bo & $\mathrm{OK}$ \\
\hline C $52 \mathrm{P}$ & 0.35 & 0.11 & 0.98 & Bo & Bo & $\mathrm{OK}$ \\
\hline C $53 \mathrm{P}$ & 0.68 & 0.67 & 0.45 & $\mathrm{~F}$ & $\mathrm{~F}$ & OK \\
\hline C $54 \mathrm{P}$ & 1.17 & 1.03 & 3.50 & Bo & Bo & $\mathrm{OK}$ \\
\hline C $55 \mathrm{P}$ & 0.39 & 0.21 & 1.14 & Bo & Bo & $\mathrm{OK}$ \\
\hline C $56 \mathrm{P}$ & 0.64 & 0.63 & 0.44 & $\mathrm{~F}$ & $\mathrm{~F}$ & $\mathrm{OK}$ \\
\hline C $51 \mathrm{M}$ & 0.61 & 0.47 & 2.10 & Bo & Bo & OK \\
\hline C $53 \mathrm{M}$ & 0.57 & 0.55 & 0.33 & $\mathrm{~F}$ & $\mathrm{~F}$ & $\mathrm{OK}$ \\
\hline C $54 \mathrm{M}$ & 0.95 & 0.79 & 3.10 & Bo & Bo & $\mathrm{OK}$ \\
\hline $\mathrm{C} 56 \mathrm{M}$ & 0.51 & 0.52 & 0.50 & $\mathrm{~F}$ & $\mathrm{~F}$ & $\mathrm{OK}$ \\
\hline C $61 \mathrm{M}$ & 0.37 & 0.32 & 1.24 & Bo & Bo & $\mathrm{OK}$ \\
\hline C $61 \mathrm{P}$ & 0.16 & 0.29 & 1.69 & $\mathrm{~S}$ & $\mathrm{~S}$ & $\mathrm{OK}$ \\
\hline C $62 \mathrm{P}$ & 0.15 & 0.44 & 0.66 & $\mathrm{~S}$ & S/Bo & $\mathrm{OK}$ \\
\hline C $63 \mathrm{P}$ & 0.17 & 0.40 & 0.43 & $\mathrm{~S}$ & $\mathrm{~S} / \mathrm{Bo}$ & OK \\
\hline C $64 \mathrm{P}$ & 0.35 & 0.25 & 1.66 & Bo & $\mathrm{S}$ & NG \\
\hline C $65 \mathrm{P}$ & 0.28 & 0.23 & 2.08 & Bo & S/Bo & $\mathrm{OK}$ \\
\hline C $66 \mathrm{P}$ & 0.26 & 0.46 & 1.05 & $\mathrm{~S}$ & $\mathrm{~S}$ & OK \\
\hline C $67 \mathrm{P}$ & 0.15 & 0.36 & 1.09 & $\mathrm{~S}$ & $\mathrm{~S} / \mathrm{Bo}$ & $\mathrm{OK}$ \\
\hline C $68 \mathrm{P}$ & 0.29 & 0.53 & 0.63 & $\mathrm{~S}$ & $\mathrm{~S}$ & OK \\
\hline C $68 \mathrm{M}$ & 0.28 & 0.59 & 0.52 & $\mathrm{~S}$ & S/Bo & $\mathrm{OK}$ \\
\hline
\end{tabular}

Table 2 Error Analysis

S : shear Bo: Bond Splitting F : Flexure

$/$ : coincident occurrence

specimens C $51 \mathrm{P}, \mathrm{C} 54 \mathrm{P}$ and C $54 \mathrm{M}$. Hence, such observations made on the error analysis acts as an aid in the improvement of the design equations for columns especially on the bond splitting aspect. As for NG remark on specimen C $64 \mathrm{P}$, the main reason lies in the underestimation of the calculated shear and bond splitting capacities, thereby giving a wrong classification on the resulting failure mode. 


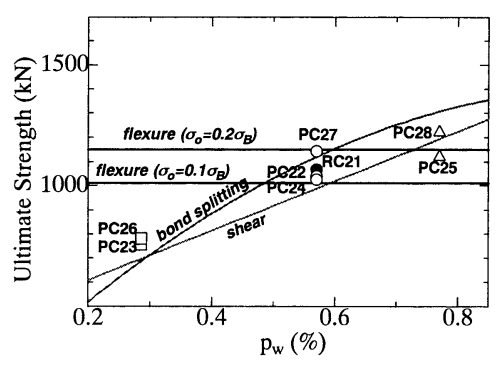

(a) columns RC21 PC28

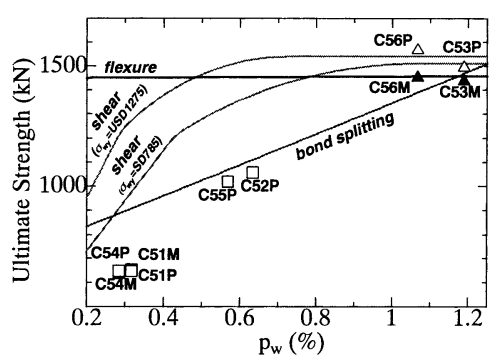

(d) columns C51P $\sim$ C56M

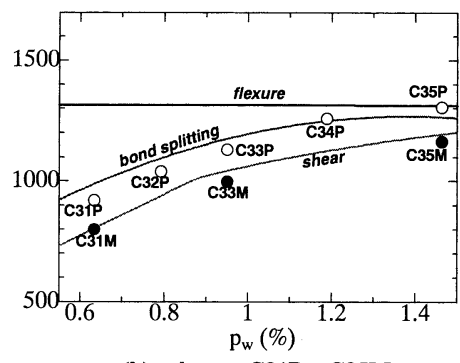

(b) columns C31P $\sim \mathbf{C 3 5 M}$

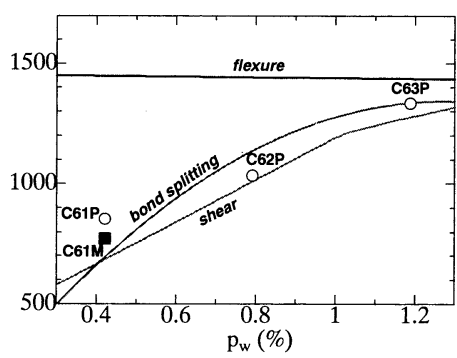

(e) columns $\mathrm{C61M} \sim \mathrm{C} 63 \mathrm{P}$

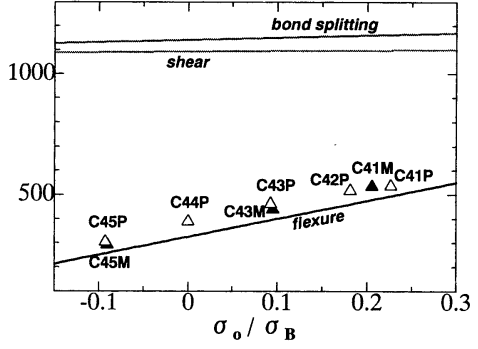

(c) columns C41P C C45M

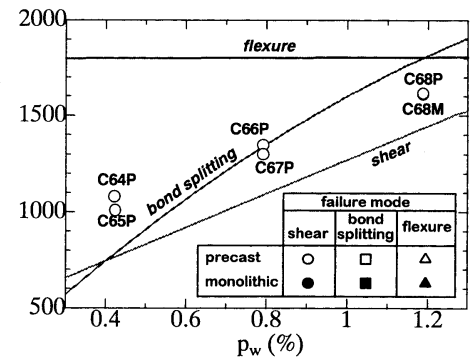

(f) columns C64P $\sim \mathrm{C68M}$

Fig. 12 Ultimate Strength Calculations

\subsection{Ultimate Strength}

From the analysis and conclusions obtained by using the main bar strain distribution, a discussion on the ultimate strength of reinforced concrete columns is considered. Emphasis is given on the calculation of the bond splitting capacities mainly due to the adjustment made by considering the effect of the inner rows of main reinforcement. Figure 12 shows the plots of the theoretical ultimate strengths according to the different failure modes against the experimental values. For this comparative analysis, only the theoretical bond splitting capacities based on the proposed equation by Kaku are shown since from the results, values obtained using the Kaku equation showed closer estimates of the experimental bond splitting strengths compared to the ones obtained using the Fujii-Morita equation.

Considering the figures individually, it could be observed, for columns RC 21 PC 28 in Fig. 12 (a), that the predicted failure mode agrees well with the actual resulting failure mode with the adjustments made on the bond splitting capacities. This holds true for all the failure types, namely bond splitting (PC 23 \& PC 26), shear (RC 21, PC 22, PC $24 \&$ PC 27) and flexure (PC 25 \& PC 28). Next, for columns C $31 \mathrm{P} \sim \mathrm{C} 35 \mathrm{M}$ (shear type) and columns $\mathrm{C} 41 \mathrm{P} \sim \mathrm{C} 45 \mathrm{M}$ (flexure type) in Figs. 12 (b) and (c), an accurate correspondence could be seen for all specimens tested.

Moreover, for columns C $51 \mathrm{P} \sim \mathrm{C} 56 \mathrm{M}$ in Fig. 12 (d), a fairly good agreement could also be observed except that, for the specimens with a low amount of lateral reinforcement $\left(p_{w} \leq 0.32 \%\right)$, there is an overestimation on the calculated bond splitting capacities. The low amount of lateral reinforcement is characterized by the absence of inner hoops and that only peripheral hoops are fabricated inside. Therefore, a probable cause for the decrease in the experimental bond splitting strengths of the columns would be the absence of inner lateral hoops. Finally, for columns C 61 $\mathrm{M} \sim \mathrm{C} 68 \mathrm{M}$ in Figs. 12 (e) and (f), an analysis on the shear capacity calculations is given. It could be observed that the theoretical shear strength of the columns is a little underestimated for the specimens especially for the high-strength concrete type (C $64 \mathrm{P} \sim \mathrm{C} 68 \mathrm{M}$ ). This could be attributed to the use of higher strength concrete wherein the concrete could carry a much larger load than the load determined theoretically. Further researches on the aforementioned inaccuracies in the calculations, either for shear of bond splitting, are necessary to have better estimation 
of the ultimate strengths of reinforced concrete columns.

\section{CONCLUSIONS}

This study is focused on the determination of the resulting failure mode based on the truss and arch model theory. Using the experimental strains in the main reinforcement and with proper consideration of the presence of inner main bars and axial loading, it can be concluded that the classification of the resulting failure mode is generally accurate for both the qualitative and quantitative aspects. In the case of shear and flexural failure, results show that the use of the main bar strain distribution is fairly good. On the other hand, for the bond splitting type, an improvement in the calculation of the reinforced concrete column capacity with proper consideration of the inner rows of main reinforcement is deemed necessary.

It should also be noted that the proposed classification method supports the validity of the use of the truss and arch mechanisms in the determination of the ultimate strengths of reinforced concrete columns especially for the shear and bond splitting capacities.

\section{ACKNOWLEDGEMENTS}

The authors would like to express their gratitude to the Kabuki Construction Company, especially to Teruaki Yamaguchi, Kouichi Hibino and Juan Jose Castro, for their support during the experiment. Also, to the members of the Imai Laboratory and Asst. Prof. Toshiyuki Kanakubo of the University of Tsukuba, for their assistance during the experiments and contribution in the analysis of the data gathered.

\section{REFERENCES}

1) Architectural Institute of Japan : AIJ Structural Design Guidelines for Reinforced Concrete Build ings, 1994

2) Fujii, S. and S. Morita : Splitting Bond Capacities of Deformed Bars, Part 1 Experimental studies on main factors influencing splitting bond failure, Trans. of the AIJ, Vol. 319, pp. 47-55, Sept. 1982

3) Fujii, S. and S. Morita : Splitting Bond Capacities of Deformed Bars, Part 2 A proposed ultimate strength equation for splitting bond failure, Trans. of the AIJ, Vol. 324, pp. 45-53, Feb. 1983

4) Kaku, T. et al : The Proposal of Equation for Bond Splitting Strength of Reinforced Concrete Members Including High Strength Concrete Level, Concrete Research and Technology, Vol. 3, No. 1, pp. 97-108, Jan. 1992

5) Kaku, T. et al : Influence of Yield Stress of Transverse Reinforcement on the Bond Strength of Reinforced Concrete Members, Proc. of the JCI, Vol. 16, No. 2, pp. 247-252, 1994

6) Muto, K. : Plastic Design of Reinforced Concrete Structures, Seismic Design Series 2, Tokyo, 1964

7) Nigel Priestley, M. J. et al : Seismic Shear Strength of Reinforced Concrete Columns, Journal of Structural Engineering of the ASCE, Vol. 120, No. 8, pp. 2310-2329, Aug. 1994

8) Kobayashi, T. et al : An Experimental Study of the Seismic Performance of Precast Concrete Columns under Shear Forces, Trans. of the JCI, Vol. 14, pp. 409-416, 1992

9) Alcantara, P. A. et al : A Study on the Influence of Shear Reinforcement Ratios to the Seismic Performance of Precast Concrete Columns, Trans. of the JCI, Vol. 17, pp. 173-180, 1995

10) Alcantara, P. A. et al : A Research on the Seismic Behavior of Precast Concrete Columns using High-Strength Shear Reinforcement, Proc. of the JCI, Vol. 19, No. 2, pp. 963-968, 1997

11) Alcantara, P. A. et al : The Seismic Behavior of Precast Columns using High-Strength Concrete subjected under High Axial Loading, Proc. of the JCI, Vol. 20, No. 3, pp. 487-492, 1998

12) Nomoto, T. and H. Imai : A Study on the Flexural Performance of Precast Concrete Columns of Main Bar Post Insertion System, Proc. of the First Asia-Pacific Conference on Offshore System: Mobile and Floating Structures, pp. 113-119, 1996

13) Imai, H. : Precast Methods for Frame Type Buildings, Proc. of the Fourth International Conference on Structural Failure, Durability and Retrofitting, pp. 396-403, 1993

14) Yanez, R. et al : Study on the Bond Splitting Strength of Sheaths for a Precast Concrete System, Trans. of the AIJ, Vol. 473, pp. 137-148, Jul. 1995

15) Walpole, R. E. and R. H. Myers : Probability and Statistics for Engineers and Scientists, Second Edition, New York, 1978

（原稿受理年月日 : 1998 年 7 月 9 日） 
アーチ・トラスモデルに基づき主筋歪分布の解析より $\mathrm{RC}$ 柱の破壊モードを判別する方法 アルカンタラ プリモアラン・今井 弘

Concrete Research and Technology, Vol. 10, No. 2, May 1999

概 要 鉄筋コンクリート柱の破壊形式を，せん断破壊型，付着破壊型，および曲げ破壊型に分類する方法を新た に提案した。従来の方法では, ひび割れ状況や最大耐力, および主筋や横補強筋の降伏の有無等に基づいて定性的に 破壊形式を決めていたが，破壊形式の判別が困難な場合があった。本論文で提案する方法では，主筋のひずみの理論 值は，せん断破壊型と付着破壊型に対してはアーチ・トラスモデルの基づいて中段主筋と軸力の影響を適切に考慮し て求める。また，曲げ破壊型に対しては，平面保持を仮定して求める。次に，せん断と付着，および曲げの 3 つの破 壊形式に対し, 主筋の歪分布の理論值と実験值の差の 2 乗和の平方根を, 実験值の 2 乗和の平方根で除して, 理論值 と実験值の誤差率を求める。各破壊形式に関して求められた誤差率のうち, 最も小さい誤差率を示す破壊形式が解析 的に求めた破壊形式となる。この方法を適用して, 鉄筋コンクリート柱の破壊形式を 44 体中 43 体に対し正確に分類 することができた。本判別方法が高い精度を示すことは, アーチ・トラスモデルが適切なモデルであることを示すこ とでもある。

キーワード：破壊形式の判別, 鉄筋コンクリート柱, アーチ・トラスモデル, 主筋の歪分布, 軸力, 中段主筋, 誤 差率 